\title{
STUDI KOMPARASI PRESTASI BELAJAR PAI ANTARA SISWA AKTIVIS DAN NON AKTIVIS ROHIS
}

\author{
Oleh. \\ Bayu Ardiwansyah \\ STKIP PGRI Metro \\ bayu21polos@gmail.com
}

\begin{abstract}
This study aims to 1) find out the significance of the differences in PAI learning achievement between activist students and Spiritual nonvisionary students in Accounting majors at SMKN 1 Metro 2) knowing the causes of differences in PAI learning achievement between activist students and non-religious Spiritual students in Accounting at SMKN 1 Metro. Rohis activist students referred to in this study are students who in addition to learning, they are also active in carrying out the activities of the Rohis organization. Whereas the non-religious Spiritual students referred to in this study were students who did not follow the Rohis organization. The results of the research at SMK Negeri 1 Metro, which researchers did to students Spiritual and Nonactivist Rohis activists concluded that: 1) There are differences in learning achievement of Islamic Education between activist students and Non-Christian Spiritual Accounting Department at Metro 1 Vocational School. Where the learning achievements of Spiritual activist PAI students are better than the learning achievements of Rohan Nonaktivis students. The difference in learning achievement of Islamic Education between activist students and Spiritual Non-Service Students is significant, based on the results of $t$ count $=4.630$ consulted with t table (tt) at the significance level of $5 \%=1.998$ and at $1 \%$ significance level $=2.655$. or $1,998\langle 4,630\rangle 2,655$. which means significant. 2) There are causes of differences in PAI learning achievements between activist students and non-religious Rohis students in the Accounting Department at SMK Negeri 1 Metro.
\end{abstract}

Keywords: Activists, Non Activists, PAI Achievements, Comparative

\begin{abstract}
Abstrak
Penelitian ini bertujuan untuk 1) mengetahui seberapa besar signifikansi perbedaan prestasi belajar PAI antara siswa aktivis dan siswa nonaktivis Rohis pada jurusan Akuntansi di SMKN 1 Metro 2) mengetahui faktor penyebab perbedaan prestasi belajar PAI antara siswa aktivis dan siswa nonaktivis Rohis pada jurusan Akuntansi di SMKN 1 Metro. siswa aktivis Rohis yang dimaksud dalam penelitian ini adalah siswa yang selain belajar, mereka juga aktif dalam pelaksanaan kegiatan organisasi Rohis. Sedangkan siswa nonaktivis Rohis yang dimaksud dalam penelitian ini adalah siswa yang tidak
\end{abstract}


mengikuti organisasi Rohis. Hasil penelitian di SMK Negeri 1 Metro, yang peneliti lakukan pada siswa Aktivis Rohis dan Nonaktivis Rohis menunjukan simpulan bahwa : 1) Terdapat perbedaan prestasi belajar Pendidikan Agama Islam antara siswa aktivis dan Nonaktivis Rohis Jurusan Akuntansi di SMKN 1 Metro. Di mana prestasi belajar PAI siswa aktivis Rohis lebih baik dari prestasi belajar PAI siswa Nonaktivis Rohis. Perbedaan prestasi belajar Pendidikan Agama Islam antara siswa aktivis dan Nonaktivis Rohis bersifat signifikan, didasarkan pada hasil t hitung $=4,630$ dikonsultasikan dengan $\mathrm{t}$ tabel ( tt ) pada taraf signifikansi $5 \%=1,998$ dan pada taraf signifikansi $1 \%$ $=2,655$. atau 1,998 < 4,630 2,655. yang berarti signifikan. 2) Ada penyebab perbedaan prestasi belajar PAI antara siswa aktivis dengan nonaktivis Rohis pada Jurusan Akuntansi di SMK Negeri 1 Metro.

\section{Kata Kunci: Aktivis, Non Aktivis, Prestasi PAI, Komparasi}

\section{A. PENDAHULUAN}

Pendidikan merupakan faktor penting yang turut menentukan pembangunan suatu Bangsa dan Negara. Di Indonesia Pendidikan menjadi sektor yang mendapat prioritas dari pemerintah sebagai upaya untuk meningkatkan kualitas manusia Indonesia seutuhnya. Untuk itu menjadi hak setiap anak bangsa untuk mendapatkan pendidikan, baik pendidikan secara formal maupun non formal. " Pendidikan formal adalah jalur pendidikan yang berstruktur dan berjenjang yang terdiri atas pendidikan dasar, pendidikan menengah dan pendidikan tinggi. Sedangkan pendidikan non formal adalah jalur pendidikan diluar pendidikan formal yang dapat dilaksanakan secara terstruktur dan berjenjang “. 1

SMK Negeri 1 Metro merupakan salah satu jalur pendidikan formal yang berstruktur dan berjenjang pendidikan

${ }^{1}$ Departemen Pendidikan Nasional RI, UU RI No. 20 tahun 2003 tentang Sisdiknas ( Sistem Pendidikan Nasional ), ( Jakarta : Sinar Grafika , 2003 ), hal. 3. menengah. Sebagai lembaga pendidikan formal SMK memiliki peran yang cukup urgent dalam rangka mengembangkan nilai-nilai dan potensi yang dimiliki siswa menuju manusia dewasa yang memiliki kekuatan spiritual keagamaan, kecerdasan, akhlak mulia serta ketrampilan yang diperlukan siswa. Hal ini sejalan dengan tujuan pendidikan yang tercantum dalam Undang - Undang No. 20 tentang Sistim Pendidikan Nasional bahwa:" Pendidikan Nasional bertujuan untuk berkembangnya potensi peserta didik yang beriman dan bertakwa kepada Tuhan Yang Maha Esa, berakhlak mulia, sehat, berilmu, cakap, kreatif, mandiri, menjadi warga Negara yang demokratis dan bertanggung jawab". ${ }^{2}$

Tujuan tersebut tidak lepas dari tujuan pendidikan Islam. Tujuan pendidikan Islam biasanya digambarkan dalam perspektif, yaitu manusia ideal seperti insan kamil, muslim paripurna, manusia yang ber-

\footnotetext{
${ }^{2}$ Ibid., h. 5.
} 
imtaq dan berip-tek dan lain sebagainya. Oleh karena itu ilmu yang harus dimiliki manusia dalam usahanya mencapai kebahagiaan dunia dan akhirat diantaranya adalah melalui Pendidikan Agama Islam.

Alokasi waktu adalah penyediaan waktunya yang hanya 2 (dua) jam pelajaran dalam seminggu dirasa kurang bisa memberikan hasil yang memuaskan, sehingga hal ini menjadikan alasan pentingnya menyelenggarakan kegiatan ekstrakurikuler yang diharapkan bisa membantu siswa untuk lebih memahami materi pelajaran khususnya pendidikan agama Islam serta mendukung pencapaian prestasi siswa lebih baik lagi.

Satu kegiatan ekstrakurikuler di SMKN 1 yang bergerak dalam bidang keagamaan yaitu organisasi Rohani Islam atau yang biasa disingkat ROHIS. Rohis disini sebagai organisasi penggerak dakwah di sekolah yang perannya begitu besar dalam membantu dan membina nilai - nilai baik siswa. Nugroho Widiyantoro mengemuka kan bahwa " ada tiga alasan utama yang menjelaskan urgensi dakwah sekolah yakni efektif, Masif dan strategis ". 3

Dewasa ini pendidikan agama menjadi sorotan tajam masyarakat karena banyaknya perilaku menyimpang peserta didik dan remaja pada umumnya yang tidak sesuai dengan norma agama. Media cetak dan

\footnotetext{
Nugroho Widiyantoro, Panduan Dakwah Sekolah, Kerja Besar Untuk Perubahan Besar ( Bandung :PT. Syaamil Cipta Media,2005 ), hal. 29.
}

elektronik pun sering memberitakan perilaku amoral peserta didik di sekolah mulai dari penyalahgunaan narkoba, seks bebas hingga aksi kekerasan (tawuran) sangat mengganggu ketertiban dan keamanan masyarakat.

Fenomena tersebut seakan menunjukan rendahnya kualitas Pendidikan Agama Islam di sekolah sebagai mata pelajaran yang mengedepankan pendidikan dibidang akhlak dan perilaku. Walaupun rendahnya kualitas pendidikan agama Islam di sekolah bukan merupakan satu-satunya faktor penyebab terjadinya perilaku peserta didik sebagaimana dijelaskan di atas, namun tetap peran PAI harus menjadi agen perubahan (agent of change) dalam merubah perilaku siswa kearah lebih baik. Sehingga pada akhirnya kegiatan ekstrakurikler seperti Rohis menjadi salah satu wadah atau alternative guna menambah pemahaman agama, juga sebagai langkah prefentif pada hal - hal buruk yang tidak diharapkan terjadi pada siswa.

Anggota Rohis terdiri dari kelas X dan kelas XI, sedangkan kelas XII sudah tidak mengikuti organisasi karena difokuskan untuk menghadapi Ujian Nasional ( UN ), oleh karena itu yang menjadi fokus dalam kajian ini adalah siswa kelas X dan XI.Apapun jenis kegiatan siswa di sekolah, mereka tetap peserta didik yang selalu dituntut untuk memiliki prestasi belajar yang baik dalam evaluasi belajar di sekolah. Hasil dari kegiatan kurikuler Pendidikan Islam dapat dilihat dari prestasi belajar Pendidikan Agama 
Islam siswa. Prestasi belajar penting untuk diukur dan diberikan kepada siswa sebagai umpan balik, motivasi bagi siswa, namun tinggi dan rendahnya suatu prestasi belajar dipengaruhi oleh beberapa faktor. Menurut Slameto factor-faktor yang mempengaruhi prestasi belajar digolongkan menjadi dua bagian utama yaitu " faktor intern dan faktor ekstern, faktor intern adalah suatu faktor yang berasal dari dalam diri siswa dan faktor ekstern adalah faktor yang berasal dari luar diri siswa “. ${ }^{4}$ Berdasarkan sampel yang diambil, data menunjukan bahwa ada kecenderungan prestasi belajar pendidikan agama Islam siswa aktivis lebih tinggi dibandingkan siswa nonaktivis Rohis, maka berdasar alasan itu pula, maka ruang lingkup kajian ini berupa "Studi Komparasi Prestasi Belajar Pendidikan Agama Islam Antara Siswa Aktivis dan Nonaktivis Rohis di SMK Negeri 1 Metro.

\section{B. METODE PENELITIAN}

Bentuk penelitian ini adalah penelitian kuantitatif, yaitu penelitian yang menggunakan angka-angka dan pegolahan data statistik. Penelitian ini termasuk kategori penelitian deskriptif komparatif, dengan cara data yang terkumpul diteliti dan dianalisis secara kuantitatif supaya memberikan gambaran dalam penelitian ini kaitannya dengan pengujian hipotesis. Adapun sifat penelitian ini adalah komparatif, yaitu " Penelitian yang bersifat membandingkan dua atau tiga

4 Slameto, Belajar dan Faktor Faktor yang Mempengaruhi, ( Jakarta : Rineka Cipta, 2010), hal. 54.

kejadian dengan melihat penyebab penyebabnya". 5 Populasi dalam penelitian ini adalah seluruh siswa kelas $\mathrm{X}$ dan kelas XI jurusan Akuntansi, baik yang aktivis Rohis maupun yang nonaktivis Rohis di SMK Negeri 1 Metro tahun pelajaran 2018/2019 yang berjumlah 180 siswa. peneliti mendapat data siswa yang menjadi aktivis Rohis sebanyak 36 siswa dan mendapat data jumlah siswa nonaktivis Rohis sebanyak 144 siswa. Adapun penentuan jumlah sampel dalam penelitian ini, penulis menggunakan rumus perhitungan slovin, sebagai berikut :

$\mathrm{n}=\frac{\mathrm{N}}{1+\mathrm{ne}^{2}}$

Keterangan :

n : Jumlah sampel

$\mathrm{N}$ : Jumlah Populasi

e : Batas Toleransi Kesalahan ( Error Tolerance ). ${ }^{6}$

Untuk menggunakan rumus ini, pertama ditentukan batas toleransi kesalahan yang bentuknya dinyatakan dengan prosentasi. Semakin kecil toleransi kesalahan, maka semakin akurat sampel menggambarkan populasi. Dalam penelitian ini, peneliti memiliki batas kepercayaan $95 \%$ dan memiliki batas toleransi kesalahan 5\%.

Teknik pengambilan sampel dalam penelitian ini dilakukan dengan teknik stratified random sampling, yaitu penarikan sampel dimana

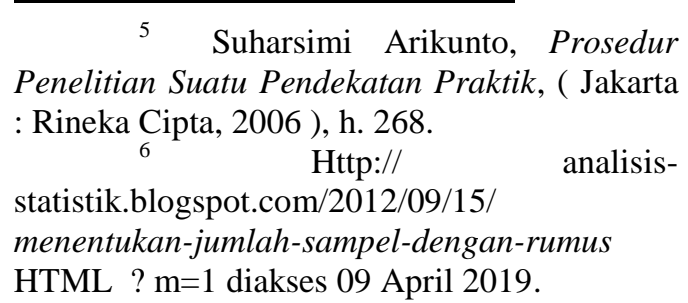


populasi dibagi-bagi dalam lapisan yang juga disebut sub populasi atau stratum ${ }^{\text {“7 }}$. Berkaitan dengan penelitian ini, populasi yang ada yaitu 180 siswa, berdasarkan perhitungan rumus slovin, maka sampel yang dibutuhkan adalah sebagai berikut :

1) Data Sampel Siswa Aktivis Rohis di SMKN 1 Metro

$$
\begin{aligned}
& \mathrm{n}=\frac{\mathrm{N}}{1+\mathrm{ne}^{2}} \\
& \mathrm{n}=\frac{36}{1+36(0,05)^{2}} \\
& \mathrm{n}=33,0275 \text { dibulatkan ke } \\
& \text { bawah menjadi } 33
\end{aligned}
$$

Jadi jumlah sampel dari siswa aktivis Rohis yang dibutuhkan berjumlah 33 siswa.

2) Data Sampel Siswa Nonaktivis

Rohis di SMKN 1 Metro

$$
\begin{aligned}
\mathrm{n} & =\frac{\mathrm{N}}{1+\mathrm{ne}^{2}} \\
\mathrm{n} & =\frac{144}{1+144(0,05)^{2}} \\
\mathrm{n} & =\begin{array}{l}
105,8823 \text { dibulatkan ke atas } \\
\text { menjadi } 106 .
\end{array}
\end{aligned}
$$

Jumlah sampel siswa Aktivis dan nonaktivis Rohis di atas jumlahnya tidak seimbang, menurut Ibnu Hadjar" Dalam penelitian komparasi jumlah sampel yang dibandingkan haruslah seimbang antara kelompok satu dengan yang lainnya,"8 sehingga untuk dapat memperoleh hasil rata-rata kedua skor

7 Edi Kusnadi, Metodologi Penelitian : Aplikasi Praktis, ( Jakarta : Ramayana Pers, 2008), hal. 85.

${ }^{8}$ Ibnu Hadjar, Dasar - Dasar Metodologi Penelitian Kuantitatif dalam pendidikan, ( Jakarta : Raja Grafindo Persada, 1999 ), hal. 148. dengan tepat, maka perlu diadakan penyesuaian jumlah sampel. Oleh karena itu untuk siswa nonaktivis Rohis jumlahnya menyesuaikan dengan jumlah siswa aktivis Rohis yakni sebanyak 33 siswa, yang dipilih secara acak ( teknik undian) dengan menggunakan nama seluruh siswa kelas X dan XI jurusan akuntansi yang nonaktivis Rohis. Dengan demikian jumlah sampel dari siswa aktivis sebesar 33 siswa dan nonaktivis Rohis sebesar 33 siswa, sehingga jumlah total sampel yang dibutuhkan adalah 66 siswa.

Metode pengumpulan data yang digunakan dalam penelitian ini adalah: Metode pengumpulan data yang pokok dalam penelitian ini, peneliti menggunakan metode dokumentasi dan angket ( Kuesioner ).Metode penunjang yang digunakan dalam penelitian ini adalah metode interview dan metode observasi.

Analisis ini digunakan untuk menguji kebenaran hipotesis yang peneliti ajukan, dalam analisis ini peneliti mengadakan perhitungan lebih lanjut mengenai tabel distribusi frekuensi yang ada, dengan menggunakan statistik yaitu $\mathrm{T}$ - Test. alasan penggunaan $\mathrm{T}$ - Test karena untuk mengetahui nilai perbedaan mean dari dua sampel dan untuk mengetes apakah secara signifikan terdapat perbedaan prestasi belajar Pendidikan Agama Islam antara siswa aktivis dan nonaktivis Rohis di SMKN 1 Metro. Rumus sebagai berikut : 


$$
t=\frac{\overline{x_{1}}-\overline{x_{2}}}{\sqrt{\frac{\left(n_{1}-1\right) s_{1}^{2}+\left(n_{1}-1\right) s_{2}^{2}}{n 1+n 2}}\left[\frac{1}{n_{1}}+\frac{1}{n_{2}}\right]}
$$

Rumus 2. (Pooled Varians)

\section{Keterangan:}

$$
\begin{gathered}
\text { = Hasil akhir dari } \\
\text { perhitungan rumus diatas } \\
\overline{x_{1}} \text { dan } \overline{x_{2}} \quad=\text { Rata-rata hitung data } \\
\text { kelompok } 1 \text { dan } 2 \\
s_{1}^{2} \text { dan } s_{2}^{2}=\text { Varian sampel data } \\
\text { kelompok } 1 \text { dan } 2 \\
n_{1} \text { dan } n_{2} \quad=\text { Banyaknya data }
\end{gathered}
$$

kelompok 2

Adapun kriteria pengujiannya

adalah : Ho diterima apabil t hitung $<\mathrm{t}$ tabel, sebaliknya Ho ditolak apabila $t$ hitung > $t$ tabel. Dengan taraf signifikansi dan dengan $\mathrm{dk}=\mathrm{n}_{1}+\mathrm{n}_{2}-2$

\section{PEMBAHASAN}

\section{Rohani Islam}

Rohani Islam atau yang biasa disebut ROHIS adalah sebuah organisasi yang bergerak dalam bidang keagamaan dan dakwah sekolah pada tingkat SMU dan sederajat. " Rohani Islam berasal dari kata " Rohani " dan " Islam ", yang berarti sebuah lembaga untuk memperkuat keislaman, yang dikemas dalam bentuk ekstrakurikuler (ekskul)." Hal ini sejalan dengan pendapat Nugroho Widiyantoro bahwa " Rohis berarti sebagai suatu wadah besar yang dimiliki oleh siswa untuk menjalankan aktivitas dakwah di sekolah." ${ }^{\text {"10 }}$ Sedangkan menurut

\footnotetext{
${ }^{9} \mathrm{Http} / / /$ iid. Wikipedia.org/wiki/rohis diakses 09 april 2019.

10 Nugroho Widiyantoro, Panduan Dakwah Sekolah, Kerja Besar Untuk
}

Departemen Agama RI rohani Islam adalah sub organisasi OSIS yang kegiatannya mendukung intrkurikuler keagamaan, dengan memberikan pendidikan, pembinaan dan pengembangan potensi peserta didik muslim agar menjadi insan beriman, bertaqwa kepada Tuhan Yang Maha Esa dan berakhlak mulia dengan mengimplementasikan ajaran Islam dalam kehidupan sehari - hari."

Berdasar pendapat di atas maka dapat dipahami bahwa Rohis merupakan organisasi yang mempunyai peran penting dalam kegiatan pengembangan dan bimbingan keagamaan yang dapat meningkatkan kompetensi Agama Islam dan kualitas keimanan dan ketaqwaan siswa agar bisa diamalkan dalam kehidupan pribadinya, baik di sekolah, di rumah atau keluarga, maupun di masyarakat sekitar. Dalam geraknya Rohis memiliki landasan syar'i yang tertuang pada firman Allah Q.S An - Nahl : 125

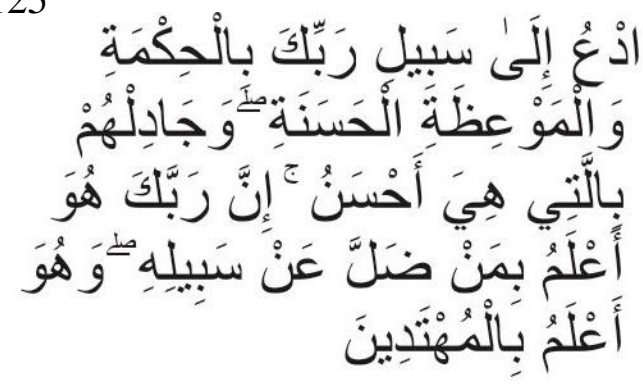

Artinya:

Serulah (manusia) kepada jalan Tuhan-mu dengan hikmah dan pelajaran yang baik dan bantahlah

Perubahan Besar ( Bandung :PT. Syamil Cipta Media,2005 ), hal. 66

11 Departemen Agama RI, Panduan Kegiatan Rohis Tingkat SMA / SMK, ( Jakarta : Depag RI, 2008 ), hal. 4. 
mereka dengan cara yang baik. Sesungguhnya Tuhanmu Dialah yang lebih mengetahui tentang siapa yang tersesat dari jalan-Nya dan Dialah yang lebih mengetahui orang-orang yang mendapat petunjuk. ${ }^{12}$

Dari landasan tersebut dapat dimaknai bahwa kegiatan Rohani Islam sangat identik dengan kegiatan dakwah, yakni kegiatan penyiaran agama Islam.

\section{Tujuan Organisasi Rohis Sekolah}

Tujuan organisasi Rohis sekolah sangat penting karena memberi arah aktivitas yang akan dilakukan. Tujuan Rohis tidak hanya berorientasi duniawi tetapi juga ukhrawi. Menurut Nugroho Widiyantoro kerohanian Islam (Rohis) bertujuan untuk mewujudkan barisan remaja-pelajar yang mendukung dan mempelopori tegaknya nilai - nilai kebenaran, mampu menghadapi tantangan masa depan. Barisan ini harus pandai memadukan aspek iman dan taqwa (imtaq) serta ilmu pengetahuan dan teknologi (iptek), Kecerdasan, kemampuan intelektual, giat belajar dan berlatih serta kedisiplinan adalah bekal dasar agar dapat menjadi manusia yang kompetetif dalam menghadapi masa depan di era globalisasi. $^{13}$

\section{Perangkat Khusus Pengkaderan Anggota Rohis}

Menurut Nugroho Widiyantoro

“ Perangkat yang paling khas dalam program pengkaderan ini adalah

${ }^{12}$ Departemen Agama RI, $A l-Q u r$ 'an dan Terjemahnya, ( Bandung : CV Penerbit Diponogoro, 2010 ), hal. 224.

${ }^{13}$ Ibid., hal. 33 program mentoring atau halaqoh tarbiyah. Halaqah inilah yang menjadi program inti pengkaderan, selain perangkat - perangkat penunjang seperti : Mabit ( menginap ), Ta'lim, Dauroh tarqiyah (Training Peningkatan), dll.)." ${ }^{\text {14 }}$ Berikut ini penjelasan mengenai perangkat pengkaderan :

a) Halaqoh

Halaqoh adalah sebuah grup pengajian / mentoring agama Islam berjumlah maksimal 12 orang, dengan keanggotaan yang relative tetap dalam jangka waktu tertentu. Jumlah yang sedikit ini akan memudahkan penyampaian materi secara intensif, pengawasan perilaku dan perkembangan peserta.

b) Mabit

Mabit adalah salah satu sarana tarbiyah ruhiyah dalam bentuk menginap bersama dengan menghidupkan malam untuk memperkuat hubungan dengan Allah, memperkuat ukuwah dan menambah bekalan dakwah.

c) Ta'lim

Ta'lim adalah bentuk yang diselenggarakan secara mandiri atau diadakan oleh pihak lain. Program ini menyertakan peserta yang lebih banyak, bersifat umum dan menghadirkan narasumber yang ahli dibidangnya.

d) Dauroh atau pelatihan

Dauroh adalah forum intensif untuk mendalami suatu ketrampilan tertentu dengan narasumber yang ahli dibidangnya. Waktu dauroh 
biasanya 1 hari penuh hingga 1 pekan (tergantung tema)

\section{Program Rohis secara Umum}

Aktivitas atau kegiatan Rohis diselaraskan dengan misi-nya, Menurut Nugroho Widiyantoro kegiatankegiatan dakwah di sekolah dibagi menjadi dua sifat, yakni bersifat amah (umum) dan bersifat khashah (khusus), dakwah ammah adalah dakwah yang dilakukan dengan cara yang umum. Dakwah amah dalam sekolah adalah proses penyebaran fikrah islamiyah dalam rangka menarik simpati, dan meraih dukungan dari lingkungan sekolah. ${ }^{15}$ Karena sifatnya demikian, dakwah ini harus dibuat dalam bentuk yang menarik, sehingga memunculkan objek untuk mengikutinya.

Dakwah umum meliputi :

1) Penyambutan siswa baru

Program ini khusus di adakan untuk penyambutan adik - adik yang menjadi siswa baru, target program ini adalah mengenalkan siswa baru dengan berbagai kegiatan dakwah sekolah, para pengurus dan alumninya.

2) Penyuluhan problem remaja

Program penyuluhan problematika remaja seperti narkoba, tawuran dan seks bebas. Program seperti ini juga menarik minat para siswa karena permasalahan ini sangant dekat dengan kehidupan mereka dan dapatt memenuhi rasa ingin tahu mereka secara positif.

3) Rihlah / Tafakkur Alam

\footnotetext{
${ }^{15}$ Ibid., hal. 88
}

Rihlah bertujuan untuk menyegarkan kembali jiwa yang penat sambil menghayati kebesaran pencipataan Allah swt dan menguatkan ukuwah. Biasanya berlangsung $1-3$ hari dan diadakan di luar kota seperti pegunungan, taman, pantai dan sebagainya.

4) Bazar dan Pameran

Bazar yang dimaksud adalah bazar buku, majalah, kaset, VCD, busana dan berbagai produk islami lainnya. Program ini biasanya menjadi program pelengkap PHBI atau momen kegiatan - kegiatan Islam lainnya.

5) Perlombaan

Program perlombaan biasa diikutkan dalam program utama PHBI sebagai wahana menjaring bakat dan minat para siswa dibidang keagamaan, ajang ta'aruf dan silaturahmi antar kelas yang berbeda.

\section{Siswa Aktivis dan Siswa Nonaktivis Rohis \\ Dalam Kamus Besar Bahasa} Indonesia " kata siswa berarti murid atau pelajar." "16 Menurut Oemar hamalik " Murid adalah salah satu komponen dalam pengajaran, sebagai salah satu komponen yang terpenting di antara komponen lainnya."17 Dari pendapat tersebut jelaslah bahwa siswa adalah subyek pendidikan yang sangat berpengaruh terhadap proses belajar mengajar. Dalam penelitian ini yang digunakan adalah kata siswa.

16 Departemen Pendidikan Nasional, Kamus Besar Bahasa Indonesia, ( Jakarta : Balai Pustaka, 2001 ), hal. 1077.

17 Oemar Hamalik, Proses Belajar mengajar, (Jakarta ; Bumi Aksara, 2011), hal. 99. 
Kata aktivis Rohis terdiri dari kata dasar yaitu " aktivis ", dan “ Rohis “. Kata " aktivis " dalam Kamus Besar Bahasa Indonesia di artikan "orang yang bekerja aktif dalam pelaksanaan suatu atau berbagai kegiatan organisasinya““ ${ }^{18}$ Sedangkan Rohis adalah organisasi yang telah diberi amanah untuk mengelola dakwah di sekolah. Sehingga siswa aktivis Rohis yang dimaksud dalam penelitian ini adalah siswa yang selain belajar, mereka juga aktif dalam pelaksanaan kegiatan organisasi Rohis. Sedangkan siswa nonaktivis Rohis yang dimaksud dalam penelitian ini adalah siswa yang tidak mengikuti organisasi Rohis atau bahkan tidak mengikuti kegiatan organisasi apapun yang ada di sekolah.

\section{Prestasi Belajar Pendidikan \\ Agama Islam}

Dalam dunia pendidikan yang ingin dihasilkan siswa dari pelaksanaan proses belajar disebut prestasi belajar.

Suharsimi Arikunto mengemukakan bahwa "Prestasi belajar merupakan hasil dari kegiatan belajar mengajar." ${ }^{19}$ Menurut Ngalim Purwanto “ Prestasi belajar adalah hasil - hasil belajar yang telah diberikan oleh guru kepada murid - muridnya, atau oleh dosen kepada mahasiswa, dalam jangka waktu tertentu“. ${ }^{20}$ Sehingga dapat dipahami bahwa prestasi belajar pada

18 Departemen Pendidikan Nasional, Op.Cit., hal.17.

${ }^{19}$ Suharsimi Arikunto, Dasar - Dasar Evaluasi Pendidikan, ( Jakarta : Bumi Aksara, 2012), hal. 4.

20 M. Ngalim Purwanto, Prinsip prinsip dan Teknik Evaluasi Pengajaran, ( Bandung : Remaja Rosdakarya, 2002 ), hal. 33. dasarnya merupakan hasil yang dicapai dari usaha dan aktivitas yang dilakukan siswa yaitu belajar mengajar.

Pendidikan Agama Islam dalam GBPP PAI di sekolah umum, sebagaimana dikutip oleh Muhaimin et.al, adalah Usaha sadar untuk menyiapkan siswa dalam meyakini, memahami, menghayati, dan mengamalkan Agama Islam melalui kegiatan bimbingan pengajaran dengan memperhatikan tuntunan untuk mengamati agama lain dalam hubungan kerukunan antar umat beragama dalam masyarakat untuk mewujudkan persatuan Nasional. ${ }^{21}$ Menurut Ramayulis " Pendidikan Agama Islam adalah upaya sadar dan terencana dalam menyiapkan peserta didik untuk mengenal, memahami, menghayati, mengimani, bertaqwa, berakhlak mulia, mengamalkan ajaran agama Islam dari sumber utamanya kitab suci Al-Qur'an dan Al-Hadits, melalui kegiatan bimbingan, pengajaran latihan serta penggunaan pengalaman. $^{22}$

Berdasarkan pendapat tersebut dapat dipahami bahwa yang dimaksud Pendidikan Agama Islam adalah usaha sadar untuk mempersiapkan peserta didik dalam menguasai ajaran - ajaran Islam, menuju kearah terbentuknya kepribadian muslim yang muttaqin. Dalam hal ini usaha untuk mempersiapkan peserta didik yang dimaksud dimulai melalui pendidikan

21 Muhaimin et.al, Paradigma Pendidikan Islam, ( Bandung : Remaja Rosda Karya, 2002 ), hal.75

${ }^{22}$ Ramayulis, Metodologi Pendidikan Agama Islam, ( Jakarta : kalam Mulia, 2005 ), hal. 21 
formal di sekolah melalui bidang studi Pendidikan Agama Islam. Dengan demikian prestasi belajar Pendidikan Agama Islam adalah hasil yang dicapai atau atau ditunjukan oleh siswa sebagai hasil belajar pada mata pelajaran Pendidikan Agama Islam. Prestasi dapat dinyatakan dalam berbagai indikator berupa nilai raport atau legger, indeks prestasi studi, angka kelulusan, prediksi kelulusan dan semacamnya. Dasar prestasi belajar PAI yang dijadikan acuan pada penelitian ini adalah data prestasi yang diambil dari legger nilai raport PAI.

\section{Faktor-Faktor \\ yang}

\section{Mempengaruhi Prestasi Belajar}

Dalam beberapa literatur, para ahli seakan bersepakat bahwa prestasi belajar dipengaruhi oleh dua faktor utama yaitu faktor Intern dan faktor ekstern individu. Menurut Slameto “ faktor intern adalah faktor yang dalam diri individu yang sedang belajar, sedangkan faktor ekstern adalah faktor yang ada di luar diri individu ". 23

Menurut Abu Ahmadi dan Widodo Supriyono, faktor-faktor yang mempengaruhi prestasi belajar terbagi menjadi 2 golongan yaitu :

1) Faktor intern meliputi :

a. Faktor Jasmaniah ( Fisiologi )

baik yang bersifat bawaan

maupun yang diperoleh. Yang

termasuk faktor ini misalnya

penglihatan, pendengaran,

struktur tubuh san sebagainya

b. Faktor Psikologis antara lain: Intelegensi, bakat, minat,

23 Slameto, Belajar dan Faktor Faktor yang Mempengaruhi, ( Jakarta : Rineka Cipta, 2010 ), hal. 54. motivasi, emosi, penyesuaian diri.

c. Faktor kematangan fisik dan psikis

2) Faktor Eksternal meliputi :

a. Faktor Sosial yang terdiri atas: Lingkungan keluarga, lingkungan sekolah, lingkungan masyarakat,

b. Faktor Budaya seperti : adat istiadat, ilmu pengetahuan, teknologi, kesenian

c. Faktor lingkungan Fisik seperti : Fasilitas rumah, fasilitas belajar, iklim. $^{24}$

Menurut Abdul Rahman Saleh dan Muhbib Abdul wahab, faktor faktor yang mempengaruhi belajar dibedakan manjadi dua golongan :

1) Faktor yang ada pada diri organisme itu sendiri yang disebut faktor individual yang meliputi : faktor kematangan / pertumbuhan, kecerdasan, latihan, motivasi dan faktor pribadi.

2) Faktor yang ada diluar individual yang disebut sosial, antara lain : faktor keluarga / keadaan rumah, guru dan cara mengajarnya, alat yang digunakan dalam mengajar, lingkungan, kesempatan yang tersedia dan motivasi sosial. $^{25}$

Menurut Slameto, Faktor-faktor yang mempengaruhi belajar digolongkan menjadi dua yaitu :

24 Abu Ahmadi dan Widodo Supriyono, Psikologi Belajar, ( Jakarta : Rineka Cipta, 2008 ), hal. 138.

${ }^{25}$ Abdul Rahman Shaleh dan Muhbib Abdul Wahab, Psikologi Suatu Pengantar ( Dalam Perspektif Islam ), ( Jakarta : Prenada media, 2004 ), hal. $224-225$. 
1) Intern yang berupa faktor jasmaniah, faktor psikologis dan faktor kelelahan ( kelelahan Jasmani dan kelelahan rohani )

2) Faktor Ekstern yang berupa faktor keluarga, faktor sekolah dan faktor masyarakat. $^{26}$

Berdasarkan pada faktor faktor tersebut dapat digeneralisasikan bahwa yang dapat mempengaruhi prestasi belajar PAI siswa dalam penelitian ini dibedakan menjadi dua faktor, yaitu :

a. Faktor intern yaitu kesehatan, motivasi, bakat dan minat.

b. Faktor ekstern yaitu faktor guru, keluarga ( suasana rumah ) dan waktu belajar.

8. Studi Komparasi Prestasi Belajar PAI antara Siswa Aktivis dan Siswa Nonaktivis Rohis.

Prestasi belajar PAI siswa aktivis dan nonaktivis Rohis dapat dipengaruhi oleh faktor yang berasal dari dalam diri siswa (Intern) dan faktor yang berasal dari luar diri siswa (Ekstern). Faktor-faktor tersebut bisa menjadi pendukung bagi tercapainya suatu prestasi yang baik tetapi bisa juga menjadi faktor yang menghambat atau menghalangi prestasi siswa untuk menjadi baik.

Faktor yang akan mempengaruhi prestasi belajar PAI siswa aktivis sama dengan siswa nonaktivis Rohis. Siswa aktivis yang selain fokus pada kegiatan kurikuler juga memiliki tanggung jawab di kegiatan organisasi. Tetapi kegiatan

${ }^{26}$ Slameto, Op.Cit., hal. 54 - 69 organisasi yang diikuti sedikit banyak ada relevansi dengan materi Agama Islam, dalam hal ini siswa tersebut juga dapat memanfaatkan waktu, menjaga kondisi fisik, memotivasi diri dengan baik sehingga prestasi cenderung lebih tinggi dibandingkan dengan siswa nonaktivis. Siswa nonaktivis Rohis pun demikian, meski mereka memiliki waktu belajar lebih banyak, waktu istirahat yang cukup, tetapi ketika tidak didukung oleh faktor motivasi yang baik dalam belajar, minat, bakat, suasana keluarga yang nyaman, maka hal ini pun dapat menjadi penghambat dan penyebab rendahnya prestasi. Maka rumusan hipotesis yang di ajukan juga ada dua, yaitu :

\section{Hipotesis Pertama:}

Ada perbedaan signifikan prestasi belajar PAI antara siswa aktivis dengan nonaktivis Rohis pada Jurusan Akuntansi di SMK Negeri 1 Metro

\section{Hipotesis Kedua:}

Ada penyebab perbedaan prestasi belajar PAI antara siswa aktivis dengan nonaktivis Rohis pada Jurusan Akuntansi di SMK Negeri 1 Metro.

Penelitian dilkukan di SMKN 1 Metro, secara geografis SMKN 1 Metro berlokasi di jalan kemiri 15 A Iring Mulyo Kecamatan Metro Timur Lampung.

a) Visi SMK Negeri 1 Metro

Menjadi SMK berstandar nasional yang mampu menghasilkan tenaga kerja profesional tingkat menengah, yang mandiri dan mampu mengembangkan diri secara 
berkelanjutan di bidang bisnis dan manajemen serta pariwisata.

b) Misi SMK Negeri 1 Metro

1. Melaksanakan proses belajar mengajar secara profesional dan inovatif yang berwawasan mutu dengan konsep Pendidikan Sistem Ganda.

2. Menciptakan lingkungan belajar yang nyaman, aman dan kondusif untuk terciptanya suasana kerja yang sejuk dan menyenangkan.

3. Menjadikan sekolah sebagai kebanggaan seluruh warga sekolah dan masyarakat, sarat dengan prestasi dan pelayanan prima.

4. Secara bertahap meningkatkan kesejahteraan tenaga pendidik dan kependidikan demi terciptanya ketenangan kerja dan dedikasi serta loyalitas yang tinggi.

5. Memberikan pelayanan pelatihan bagi masyarakat dalam bentuk "short courses" untuk meningkatkan kemampuan di berbagai bidang keahlian.

\section{Pengujian Hipotesis}

a. Uji Persyaratan Analisis Data Uji Homogenitas

Uji homogenitas yang bertujuan untuk mengetahui apakah sampel yang diambil mempunyai varians yang sama ( homogen ) serta sebagai syarat pertimbangan penggunaan rumus hipotesis yang akan dipilih.
Tabel Penolong Pengujian Homogenitas varian

Prestasi Belajar PAI siswa aktivis Rohis ( X1 )

\begin{tabular}{|c|c|c|c|c|c|c|}
\hline No & Kelas Interval & $\mathbf{F}$ & $\begin{array}{c}\text { nilai tengah } \\
(\mathbf{X} \mathbf{~})\end{array}$ & $\mathbf{X}^{\mathbf{2}}$ & $\mathbf{f .} \mathbf{X}_{\mathbf{1}}$ & $\mathbf{f .} \mathbf{X}^{\mathbf{2}}$ \\
\hline 1 & $7,60-7,73$ & 2 & 7,67 & 58,83 & 15,34 & 117,66 \\
\hline 2 & $7,74-7,87$ & 2 & 7,81 & 60,99 & 15,62 & 121,98 \\
\hline 3 & $7,88-8,01$ & 11 & 7,95 & 63,20 & 87,45 & 695,20 \\
\hline 4 & $8,02-8,15$ & 8 & 8,09 & 65,45 & 64,72 & 523,60 \\
\hline 5 & $8,16-8,29$ & 1 & 8,23 & 67,73 & 8,23 & 67,73 \\
\hline 6 & $8,30-8,43$ & 9 & 8,37 & 70,06 & 75,33 & 630,54 \\
\hline & & $\mathbf{3 3}$ & & & $\mathbf{2 6 6 , 6 9}$ & $\mathbf{2 1 5 6 , 7 1}$ \\
\hline
\end{tabular}

Mencari Rata - Rata Mean

$\bar{x}=\frac{\sum f_{i} x_{i}}{f_{i}}$

$\frac{266,69}{33}=8,08$

Mencari Simpangan Baku ( Standar Deviasi )

$$
\begin{aligned}
& s^{2}=\frac{n \sum f_{i} x_{i}^{2}-\left(\sum f_{i} x_{i}\right)^{2}}{n(n-1)} \\
& s^{2}=\frac{33(2156,71)-(266,69)^{2}}{33(33-1)} \\
& s^{2}=\frac{71171,43-71123,56}{1056} \\
& s^{2}=\frac{47,87}{1056} \\
& s^{2}=0,045 \\
& S^{1}=\sqrt{ } 0,045 \\
& S^{1}=0,212
\end{aligned}
$$

Tabel Pembantu Homogenitas varian Prestasi Belajar PAI siswa Nonaktivis Rohis (X2)

\begin{tabular}{|c|c|c|c|c|c|c|}
\hline No & Kelas Interval & $\mathbf{F}$ & $\begin{array}{c}\text { Nilai } \\
\text { Tengah } \\
\mathbf{X} \mathbf{l}\end{array}$ & $\mathbf{X}^{\mathbf{2}}$ & $\mathbf{f . ~} \mathbf{X} \mathbf{l}$ & f. $\mathbf{X}^{\mathbf{2}}$ \\
\hline 1 & $7,55-7,67$ & 10 & 7,61 & 57,91 & 76,1 & 579,10 \\
\hline 2 & $7,68-7,80$ & 11 & 7,74 & 59,91 & 85,14 & 659,01 \\
\hline 3 & $7,81-7,93$ & 0 & 7,87 & 61,94 & 0 & 0 \\
\hline 4 & $7,94-8,06$ & 6 & 8,00 & 64,00 & 48,00 & 384,00 \\
\hline 5 & $8,07-8,19$ & 2 & 8,13 & 66,09 & 16,26 & 132,18 \\
\hline 6 & $8,20-8,32$ & 4 & 8,26 & 68,23 & 33,04 & 272,92 \\
\hline & & $\mathbf{3 3}$ & & & $\mathbf{2 5 8 , 5 4}$ & $\mathbf{2 0 2 7}, \mathbf{2 1}$ \\
\hline
\end{tabular}


Mencari Rata - Rata Mean

$\bar{x}=\frac{\sum f_{i} x_{i}}{f_{i}}$

$\frac{258,54}{33}=7,83$

Mencari Simpangan Baku ( Standar Deviasi )

$$
\begin{aligned}
s^{2} & =\frac{n \sum f_{i} x_{i}^{2}-\left(\sum f_{i} x_{i}\right)^{2}}{n(n-1)} \\
s^{2} & =\frac{33(2027,21)-(258,54)^{2}}{33(33-1)} \\
s^{2} & =\frac{66897,93-66842,93}{1056} \\
s^{2} & =\frac{55 .}{1056} \\
s^{2} & =0,052 \\
S^{1} & =\sqrt{ } 0,052 \\
S^{1} & =0,228
\end{aligned}
$$

Perhitungan Homogenitas Varian

$$
\begin{aligned}
\mathrm{F} & =\frac{\text { Varian Terbesar }}{\text { Varian terkecil }} \\
& =\frac{0,228}{0,212} \\
& =1,075 \\
& =1,08(\text { Dibulatkan ke bawah })
\end{aligned}
$$

$\mathrm{F}$ tabel dengan dk pembilang $(\mathrm{n} 1-1)$ dan dk penyebut $(\mathrm{n} 2-1),(33-1)$ dan ( $33-1$ ). F 0,05 ( $32: 32$ ), ternyata dalam $\mathrm{f}$ tabel tidak ditemukan $\mathrm{dk}$ pembilang 32. Oleh karena dk pembilang 32 terletak pada dk antara 30 dan 40, maka dilakukan interpolasi dengan cara $\mathrm{dk}$ pembilang $30+40$ dibagi 2, sehingga 1,82 +1,76=3,58 : $2=1,79$. Kriteria homogen, apabila $\mathrm{F}$ hitung > F tabel, maka varians tidak homogen, apabila $\mathrm{F}$ hitung $<$ Ftabel, maka varians homogen. Karena $\mathrm{F}$ hitung $=1,08<1,79$, maka dapat disimpulkan bahwa varians homogen.

b. Pengujian Hipotesis Pertama

Hipotesis pertama yang diajukan dalam penelitian adalah

Ha : Ada perbedaan signifikan prestasi belajar Pendidikan Agama Islam antara siswa aktivis dan nonaktivis Rohis pada Jurusan Akuntansi di SMKN 1 Metro

Ho: Tidak ada perbedaan signifikan prestasi belajar Pendidikan Agama Islam antara siswa aktivis dan nonaktivis Rohis pada Jurusan Akuntansi di SMKN 1 Metro Untuk membuktikan ada atau tidaknya perbedaan serta diterima tidaknya hipotesis yang diajukan.maka perlu dilakukan perhitungan sebagai berikut :

$$
\begin{aligned}
& t=\frac{\overline{x_{1}}-\overline{x_{2}}}{\sqrt{\frac{\left(n_{1}-1\right) s_{1}^{2}+\left(n_{1}-1\right) s_{2}^{2}}{n 1+n 2-2}\left[\frac{1}{n_{1}}+\frac{1}{n_{2}}\right]}} \\
& t=\frac{\sqrt{\frac{(33-08-\overline{7,83} 0,045+(33-1) 0,052}{33+33-2}\left[\frac{1}{33}+\frac{1}{33}\right]}}{\sqrt{\frac{(32) 0,045+(32) 0,052}{64}\left[\frac{1}{33}+\frac{1}{33}\right]}} \\
& t=\frac{0,25}{\sqrt{\frac{1,44+1,664}{64}\left[\frac{2}{33}\right]}}
\end{aligned}
$$




$$
\begin{aligned}
& t=\frac{0,25}{\sqrt{0,0029}} \\
& t=\frac{0,25}{0,054} \\
& t=4,6296629 \\
& t=4,630 \text { (dibulatkan kebawah) } \\
& \text { Berdasarkan perhitungan di }
\end{aligned}
$$
atas, dapat diketahui nilai $\mathrm{t}$ hitung $=$ 4,630. Kemudian, untuk menguji hipotesis yang telah diajukan, yaitu dengan mengkonsultasikan nilai $t$ hitung dengan $t$ pada tabel $(t t)$ baik pada taraf signifikansi $5 \%$ maupun 1 $\%$, dengan ketentuan signifikansi apabila $t$ hitung lebih besar atau sama dengan tt berarti signifikan, tetapi jika to lebih kecil daripada tt berarti tidak signifikan. Kriteria pengujiannya adalah :

Ho = ditolak jika $\mathrm{t}$ hitung $>\mathrm{t}$ tabel Ho = diterima jika $\mathrm{t}$ hitung $<\mathrm{t}$ tabel

Pada penelitian ini, diketahui $\mathrm{dk}$ adalah $(\mathrm{n} 1+\mathrm{n} 2-2)$ atau $33+33-2=$ 64. ( konsultasi pada tabel t ). Dari dk 64 diperoleh tt sebagai berikut :

1. Pada taraf signifikansi $5 \%=1,998$

2. Pada taraf signifikansi $1 \%=2,655$

Berarti t hitung $=4,630>1,998(0,05$

) $\rightarrow$ Signifikan

\section{) $\rightarrow$ Signifikan}

$$
=4,630>2,655 \quad(0,01
$$

Berdasarkan hasil konsultasi diketahui bahwa $\mathrm{t}$ hitung lebih besar dari $\mathrm{tt}$, baik pada taraf signifikansi $5 \%$ maupun $1 \%$ yang berarti Ho ditolak dan Ha diterima dan hasilnya pun signifikan, maka dapat disimpulkan bahwa ada perbedaan yang signifikan prestasi belajar PAI antara siswa aktivis dan nonaktivis Rohis pada jurusan akuntansi di SMK Negeri 1 Metro. Jadi hipotesis yang diajukan oleh peneliti dalam penelitian ini diterima kebenarannya.

c. Pengujian Hipotesis Kedua

Ha : Faktor Kesehatan, motivasi, minat, bakat, guru, keluaga dan waktu belajar adalah penyebab perbedaan prestasi belajar PAI siswa aktivis dan nonaktivis Rohis ( memiliki persentase yang besar ).

Ho : Faktor Kesehatan, motivasi, minat, bakat, guru, keluaga dan waktu belajar adalah penyebab perbedaan prestasi belajar PAI siswa aktivis dan nonaktivis Rohis ( memiliki persentase yang kecil ).

Pada hipotesis kedua ini tidak dilakukan perhitungan hipotesis dikarenakan pengujian hipotesis pertama yang menyatakan apakah terdapat perbedaan prestasi belajar PAI antara siswa aktivis dan nonaktivis Rohis pada jurusan akuntansi di SMK Negeri 1 Metro tahun ternyata berdasarkan perhitungan statistik terdapat perbedaan prestasi, maka secara otomatis, akan diperoleh penyebab perbedaan prestasi belajar tersebut.

\section{ANALISIS}

Berdasarkan hasil pengolahan dan analisa terhadap data-data yang peneliti kumpulkan maka diperoleh perhitungan hipotesis pertama yaitu uji $\mathrm{t}$, maka didapat $\mathrm{t}$ hitung $=4,630$, yang kemudian dikonsultasikan dengan $\mathrm{t}$ 
tabel dengan dk 64 dan diperoleh $\mathrm{t}$ tabel pada taraf signifikansi $5 \%=$ 1,998. dan pada taraf $1 \%=2655$. Jadi, Karena $\mathrm{t}$ hitung $>\mathrm{t}$ tabel baik pada taraf 5\% maupun 1\%, maka Ho ditolak dan Ha diterima, artinya ada perbedaan prestasi belajar Pendidikan Agama Islam siswa aktivis dan nonaktivis Rohis pada Jurusan Akuntansi di SMK Negeri 1 Metro. Siswa aktivis mendapat prestasi PAI yang lebih tinggi dibandingkan siswa nonaktivis Rohis, hal ini menunjukan bahwa kegiatan organisasi Rohis yang diikuti, tidak akan menjadi penghambat bagi siswa untuk mendapat prestasi yang tinggi, selama kegiatan organisasi tersebut relevan dengan kegiatan kurikuler. Artinya faktor - faktor yang mempengaruhi prestasi belajar bukanlah penghambat.

\section{E. KESIMPULAN}

Berdasarkan hasil penelitian di SMK Negeri 1 Metro, yang peneliti lakukan pada siswa Aktivis Rohis dan Nonaktivis Rohis menunjukan simpulan bahwa :

1. Terdapat perbedaan prestasi belajar Pendidikan Agama Islam antara siswa aktivis dan Nonaktivis Rohis Jurusan Akuntansi di SMKN 1 Metro. Di mana prestasi belajar PAI siswa aktivis Rohis lebih baik dari prestasi belajar PAI siswa Nonaktivis Rohis. Perbedaan prestasi belajar Pendidikan Agama Islam antara siswa aktivis dan Nonaktivis Rohis bersifat signifikan, didasarkan pada hasil $\mathrm{t}$ hitung = 4,630 dikonsultasikan dengan $\mathrm{t}$ tabel ( $\mathrm{tt}$ ) pada taraf signifikansi $5 \%=$
1,998 dan pada taraf signifikansi $1 \%=2,655$. atau $1,998\langle 4,630\rangle$ 2,655. yang berarti signifikan.

2. Ada penyebab perbedaan prestasi belajar PAI antara siswa aktivis dengan nonaktivis Rohis pada Jurusan Akuntansi di SMK Negeri 1 Metro.

\section{DAFTAR PUSTAKA}

Abdul Rahman Shaleh dan Muhbib Abdul Wahab, Psikologi Suatu Pengantar ( Dalam Perspektif Islam ),Jakarta : Prenada media, 2004

Abu Ahmadi dan Widodo Supriyono, Psikologi Belajar, Jakarta : Rineka Cipta, 2008

Departemen Pendidikan Nasional RI, UU RI No. 20 tahun 2003 tentang Sisdiknas ( Sistem Pendidikan Nasional ), Jakarta : Sinar Grafika , 2003

-------------, Kamus Besar Bahasa Indonesia, Jakarta : Balai Pustaka, 2001

Departemen Agama RI, Al - Qur'an dan Terjemahnya, Bandung : CV Penerbit Diponogoro, 2010 , Panduan Kegiatan Rohis Tingkat SMA / SMK, Jakarta : Depag RI, 2008

Edi Kusnadi, Metodologi Penelitian : Aplikasi Praktis, Jakarta : Ramayana Pers, 2008

Ibnu Hadjar, Dasar - Dasar Metodologi Penelitian Kuantitatif dalam pendidikan, Jakarta : Raja Grafindo Persada, 1999

M. Ngalim Purwanto, Prinsip - prinsip dan Teknik Evaluasi Pengajaran, 
Bandung : Remaja Rosdakarya, 2002

Muhaimin et.al, Paradigma Pendidikan Islam, Bandung : Remaja Rosda Karya, 2002

Nugroho Widiyantoro, Panduan Dakwah Sekolah, Kerja Besar Untuk Perubahan Besar , Bandung :PT. Syaamil Cipta Media,2005

Oemar Hamalik, Proses Belajar mengajar, Jakarta ; Bumi Aksara, 2011

Ramayulis, Metodologi Pendidikan Agama Islam, Jakarta : kalam Mulia, 2005

Slameto, Belajar dan Faktor - Faktor yang Mempengaruhi, Jakarta : Rineka Cipta, 2010

Suharsimi Arikunto, Dasar - Dasar Evaluasi Pendidikan, Jakarta : Bumi Aksara, 2012

------------, Prosedur Penelitian Suatu Pendekatan Praktik, Jakarta : Rineka Cipta, 2006

Http:// analisisstatistik.blogspot.com/2012/09/1

5/ menentukan-jumlah-sampeldengan-rumus HTML ? $\mathrm{m}=1$ diakses 09 April 2019.

http:// iid. Wikipedia.org/wiki/rohis diakses 09 april 2019. 